\title{
Expression of TRH and TRH-like peptides in a human glioblastoma-astrocytoma cell line (U-373-MG)
}

\author{
S I García, P I Porto, V N Martinez, A L Alvarez, S Finkielman \\ and $\mathbf{C}$ J Pirola
} Departamento de Sustancias Vasoactivas y Laboratorio de Cardiología Molecular, Instituto de Investigaciones Médicas 'A. Lanari', Facultad de Medicina,
Combatientes de Malvinas 3150, Buenos Aires 1427, Argentina
(Requests for offprints should be addressed to C J Pirola, Instituto de Investigaciones Médicas 'A. Lanari', Combatientes de Malvinas 3150, Capital Federal
(1427), Argentina; Email: sigryc@elsitio.net)

\begin{abstract}
The human glioblastoma-astrocytoma cell line U-373-MG shows morphological features typical of its neuroectodermal origin. Cells showed positive immunostaining for the glial fibrillary acidic protein. We used this cell culture for studying the putative production of TRH and TRH-related peptides. In a cell extract and conditioned medium, cation and anion exchange chromatography and HPLC revealed the presence of TRH and acidic TRH-like peptides which were identified, at least in part, as pGlu-Glu-ProNH ${ }_{2}$. These findings demonstrated that U-373-MG cells are able to produce and release these peptides. Further evidence of TRH synthesis

was obtained by amplification using RT-PCR of a 396 bp fragment that corresponds to the TRH precursor mRNA. Our results therefore suggest that the U-373-MG cell line may be a useful model for studying the regulation of TRH and TRH-related peptide production and the interaction of these peptides with other classical neurotransmitter systems. In fact, pilocarpine (a muscarinic cholinergic agonist) enhanced and nicotine (a nicotinic cholinergic agonist) decreased TRH and TRH-related compound production by this cell line. These data also point out that glia may produce substances with neuromodulatory action. Journal of Endocrinology (2000) 166, 697-703
\end{abstract}

\section{Introduction}

Thyrotrophin-releasing hormone (thyroliberin, TRH) was first isolated from the hypothalamus and characterized for its ability to stimulate thyrotrophin and prolactin secretion (Brownstein et al. 1974). Since then, TRH has been identified in many other regions of the brain (Johansson et al. 1980) and in the gastrointestinal tract (Leppaluoto \& Koivusalo 1978). TRH is a tripeptide with a cyclized glutamic acid residue at the $\mathrm{N}$-terminus, and a histidine and an amidated proline residue at the C-terminus (pGluHis-ProNH ${ }_{2}$ ). Generally, antisera raised against TRH recognize the $\mathrm{N}$-terminal pyroglutamic acid residue and the C-terminal prolinamide, but tolerate central substitutions. It was not until 1989 that the existence of a family of peptides structurally related to this hypothalamicreleasing factor was documented (Cockle et al. 1989, Khan et al. 1992, Gkonos et al. 1993). Three novel TRH-related peptides have been isolated, namely, an acidic tripeptide pGlu-Glu-ProNH ${ }_{2}$ (Cockle et al. 1989, del Rio-García \& Smyth 1990) and two neutral tripeptides, pGlu-PheProNH $_{2}$ and pGlu-Gln-ProNH ${ }_{2}$ (del Rio-García \& Smyth 1990, Khan et al. 1992), which may contribute to the total TRH immunoreactivity located in several tissues.
We have previously reported that TRH facilitates the pressor response to acetylcholine infused in the lateral septal area of the rat brain, increasing the number of muscarinic receptors (Pirola et al. 1983). In turn, in vitro superfusion experiments with preoptic area slices showed that cholinergic muscarinic stimulation evokes a specific TRH release (García et al. 1992). In order to find a simpler model to study classic neurotransmitter-TRH interactions, we explored whether an astrocytomaglioblastoma cell line may produce TRH and we demonstrated that these cells produce and release TRH and related peptides and that they respond to a variety of stimuli such as glucocorticoids or cholinergic agonists.

\section{Materials and Methods}

Unless indicated, all reagents were from Sigma Chemical Co., St Louis, MO, USA.

\section{Cell culture}

A human glioblastoma-astrocytoma-derived cell line (U373-MG; American Tissue Culture Collection, Rockville, 
MD, USA) was cultured as indicated by the provider. Briefly, cells were maintained in modified minimum essential medium (Eagle's) with non-essential amino acids, supplemented with $10 \%$ fetal calf serum (FCS), $2 \mathrm{mmol} / 1$ L-glutamine (Irvine Scientific, Santa Ana, CA, USA), 100 $\mathrm{U} / \mathrm{ml}$ penicillin and $100 \mu \mathrm{g} / \mathrm{ml}$ streptomycin at $37^{\circ} \mathrm{C}$ in $95 \%$ air-5\% $\mathrm{CO}_{2}$. Cells were fed twice weekly and passaged every 2 weeks adding fresh trypsin (0.25\%) solution for 5-10 min until cells detached. All the experiments were conducted at confluency with or without serum for $24-48 \mathrm{~h}$, without affecting viability. All materials for cell culture were obtained from Gibco BRL (Grand Island, NY, USA).

\section{Glial fibrillary acidic protein (GFAP) immunostaining}

The monolayer grown on coverslips of Leighton tubes and made quiescent by $48 \mathrm{~h}$ of serum deprivation were fixed for 2 min with chilled methanol plus 5\% glacial acetic acid and tested by the peroxidase-antiperoxidase (PAP) method reported by Lascano \& Berria (1983). GFAP antiserum was kindly provided by Doris Dahl, Harvard Medical School, Boston, MA, USA. Second and third antisera were obtained from commercial sources.

\section{$R T-P C R$}

Total RNA of cultured cells from a pool of two to four T75 flasks or 100-200 mg rat hypothalamic tissue used as a positive control was isolated as described by Chomczynski \& Sacchi (1987) with slight modifications. The integrity and accuracy of total RNA quantitation were confirmed by running $5 \mu \mathrm{g}$ aliquots of each sample through $1 \%$ agarose-formaldehyde gel electrophoresis and ethidium-bromide staining.

One microgram of total RNA was reverse transcribed to cDNA and amplified by a single-step protocol employing tTh DNA polymerase according to the manufacturer's instructions (Perkin Elmer, Norwalk, CT, USA). We performed 25 cycles of $2 \mathrm{~min}$ at $94^{\circ} \mathrm{C}, 2 \mathrm{~min}$ at $60{ }^{\circ} \mathrm{C}$ and $2 \mathrm{~min}$ at $70^{\circ} \mathrm{C}$ using specific primers for the TRH precursor mRNA transcript: upper: $5^{\prime}$ GCC TTG CCT TGC ACA GAT GGG AAA AC 3'; lower: 5' GAA GAG TGC AAA CTG GCT GGG TAG AG 3'. The PCR product was identified as a specific band corresponding to a $396 \mathrm{bp}$ cDNA fragment using Southern blot and hybridization with a pre-TRH cDNA probe (PLW4-2 TRH cDNA, kindly donated by Dr Lechan, Tufts University, New England Medical Center, Boston, MA, USA) labelled with ${ }^{32} \mathrm{P}-\mathrm{CTP}$ by a random priming kit following the manufacturer's instructions (New England Biolabs, Beverly, MA, USA).

Rat hypothalamus RNA was used as positive control and a negative RT-PCR control was performed by omitting the RT step.

\section{Extraction of TRH and TRH-like peptides}

For peptide extraction, medium samples were collected and adjusted to acetic acid $(2 \mathrm{~mol} / \mathrm{l}), \mathrm{HCl}(0 \cdot 1 \mathrm{~mol} / \mathrm{l})$. After removal of the medium, cells were washed twice with phosphate-buffered saline and detached by adding an acetic acid/ $\mathrm{HCl}$ solution (final concentration $2 \mathrm{~mol} /$ 1:0.1 mol/l). Cells were sonicated for $30 \mathrm{~s}$. All samples were boiled for $20 \mathrm{~min}$, centrifuged at 10000 r.p.m. and the supernatant lyophilized. The residues were dissolved in the appropiate buffer for radioimmunoassay (RIA) measurement of TRH-like immunoreactivity as described below. In some experiments, residues were resuspended in either the mobile phase or methanol for identification by HPLC or ion-exchange chromatography.

\section{TRH RIA}

RIA for TRH has been reported in detail (García et al. 1992). Briefly, a polyclonal antibody was raised against TRH in New Zealand white rabbits immunized with TRH coupled to bovine serum albumin using the bisdiazotized benzidine reaction (Bassiri \& Utiger 1972). The cross-reactivity of the antiserum was $100 \%$ for pGlu-His$\mathrm{ProNH}_{2}$ (TRH), $15 \%$ for 3-methyl-TRH, $2.5 \%$ for Glu-TRH, $0.03 \%$ for pGlu-Glu-ProNH $2, \quad 0.02 \%$ for TRH-OH and $<0.002 \%$ for Glu, His, Pro and cyclo (Hys-Pro). Standards or samples were incubated with $\left[{ }^{125} \mathrm{I}\right] \mathrm{TRH}$ and anti-TRH $(1 / 10000)$ at $4{ }^{\circ} \mathrm{C}$ overnight. Free hormone was pelleted using carbon dextran T-70. All samples were assayed in duplicate. The minimum detectable amount was $5-10 \mathrm{pg}$. Intra- and interassay coefficients of variation were less than $7 \cdot 0$ and $14 \cdot 0 \%$ respectively. Since we used synthetic TRH as the standard in our RIA, results of peptide measurements are expressed as the amount of authentic TRH that produced an identical displacement in the tracer-antibody reaction.

\section{Separation of TRH-like peptides from TRH by}

chromatography on ion-exchange mini-columns

In short, the procedure involved the addition of the dried methanol-extracted residue dissolved in $50 \%$ acetic acid to a mini-column $(6 \times 0.5 \mathrm{~cm})$ of SP-Sephadex C25 in the pyridinium form. The later was achieved by washing the column with $\mathrm{HCl}(1 \mathrm{~mol} / \mathrm{l})$ and then successively with distilled water, pyridine $(1 \mathrm{~mol} / \mathrm{l})$, distilled water and $50 \%$ acetic acid $(2 \mathrm{ml}$ each). After addition of the sample, the column was eluted in two steps with (a) $50 \%$ acetic acid $(8 \times 0.5$ fractions $)$ and (b) $0.4 \mathrm{~mol} / 1$ pyridine in $50 \%$ acetic acid $(12 \times 0.5 \mathrm{ml}$ fractions) (Boler et al. 1969). Aliquots $(250 \mu \mathrm{l})$ of each fraction were then concentrated under vacuum and the residual peptides dissolved in RIA buffer for determining TRH-like immunoreactivity.

Using this method, each peptide mixture added to the column was divided into two groups of fractions, the first 



Figure 1 Monolayer of flat, elongated, immature GFAP-positive astroglial cells (left panel $\times 5$; right panel $\times 50$ ) on day 6 of subculture. Immunolabelling shows intense GFAP staining of both cellular and processes in 48-h FCS-deprived cells.

group (fractions 3-8) containing non-retained peptides that were neutral or acidic and the second one (fractions 12-17) having retained substances positively charged. Thus, TRH was retained during the elution with $50 \%$ acetic acid while the neutral and acidic TRH-like peptides emerged without retention.

Finally, to confirm the retention of TRH in each mini-column, $\left[{ }^{125} \mathrm{I}\right] \mathrm{TRH}$ was added and measured by solid scintillation counting of the eluted fraction.

In some experiments, the remaining $250 \mu \mathrm{l}$ of each fraction were concentrated under vacuum and dissolved in methanol for HPLC or diethylamino-ethyl (DEAE) chromatography.

Separation of acidic from neutral and basic TRH-like peptides by analytical mini-column chromatography on

DEAE-Sephadex

Mini-columns $(6 \times 0.5 \mathrm{~cm})$ were prepared by pouring a suspension of DEAE-Sephadex in ammonium acetate buffer $(500 \mathrm{mmol} / \mathrm{l})$ at $\mathrm{pH} 7 \cdot 0$ and the columns were washed with $1 \mathrm{ml}$ distilled water and $2 \mathrm{ml}$ amonium acetate buffer $(25 \mathrm{mmol} / \mathrm{l}, \mathrm{pH} 7 \cdot 0)$. Dried methanolextracted residues were resuspended in $1 \mathrm{ml}$ ammonium acetate $(25 \mathrm{mmol} / \mathrm{l})$ and applied to the DEAE-Sephadex column (Boler et al. 1969). In some experiments, aliquots from each neutral or acidic TRH-like peptides resolved by the previously described cation-exchange chromatographic technique were dried in vacuum and the residues dissolved in $1 \mathrm{ml}$ ammonium acetate $(25 \mathrm{mmol} / \mathrm{l})$ for application to the DEAE column. Ten fractions $(0.5 \mathrm{ml})$ were eluted with $25 \mathrm{mmol} / 1 \mathrm{ammonium}$ acetate buffer and a further ten fractions were eluted with $500 \mathrm{mmol} / \mathrm{l}$ ammonium acetate buffer. Aliquots of each fraction were processed as described above for measuring TRH-like immunoreactivity by the RIA described.
Resolution of TRH-like peptides by HPLC

For HPLC studies, the sample was dissolved in $50 \mathrm{mmol} / 1$ triethylamine adjusted to $\mathrm{pH} 3$ with formic acid. The Waters Associates (Milford, MA, USA) chomatographic system consists of $6000 \mathrm{M}$ and 590 model pumps, a $200 \mu \mathrm{l}$ fixed loop Rheodyne injector, a Spectroflow monitor SF770 (Schoeffel Instruments, Ramsey, NJ, USA), a PC-based baseline gradient system controller, and a $4 \times 125 \mathrm{~mm}$ Lichrosphere RP-8, $5 \mu \mathrm{m}$ particle size, LichroCart cartridge (Merck, Darmstadt, Germany). The flow rate of the mobile phase $(50 \mathrm{mmol} / 1$ triethylamine adjusted to $\mathrm{pH} 3$ with formic acid) was $1 \mathrm{ml} / \mathrm{min}$. After injection, the bound material was eluted using a 60-min linear gradient $(0-80 \%)$ of methanol. Fractions $(1 \mathrm{ml})$ were collected, lyophilized, reconstituted in RIA buffer and assayed for endogenous TRH immunoreactivity by the RIA described. Synthetic peptides (pGlu-His-ProNH ${ }_{2}$ (TRH) and pGlu-Glu-ProNH ${ }_{2}$ ) were injected separately to be used as standards.

\section{Statistics}

Results are expressed as means \pm S.E.M. statistical significances were analysed by ANOVA with repeated measurements on one factor.

\section{Results}

Cell monolayers deprived of serum for $48 \mathrm{~h}$ were made up of flat elongated cells with central nuclei and abundant cytoplasm which are characteristic features of astrocytes. The PAP technique showed GFAP-positive cells. Immunolabelling showed intense GFAP staining of both the cellular body and the processes (Fig. 1). Since serum 
deprivation seemed to differentiate cell culture from highly dividing rounded cells to astrocyte-like cells, we studied the TRH-like immunoreactivity by RIA in the presence or absence of $10 \%$ FCS. The serum deprivation induced a large increase $(P<0.05)$ in the abundance of TRH-like substances from $50 \pm 35$ to $220 \pm 50 \mathrm{pg}$ $\mathrm{TRH} / \mathrm{mg}$ protein. We also found that TRH-like substances were released to the medium since an immunoreactivity similar to TRH in cell-conditioned media was detected in both conditions (cell cultured in 10\% FCS: $62 \pm 38$ vs 48 -h serum-deprived cells: $182 \pm 21 \mathrm{pg}$ $\mathrm{TRH} / \mathrm{mg}$ protein, $P<0 \cdot 05, n=9)$ and total TRH-like immunoreactivity was increased by the addition of carbachol $(1 \mu \mathrm{mol} / \mathrm{l})$ to the culture media in either condition (10\% FCS: $358 \pm 59$ and 48-h deprived cells: $807 \pm 98 \mathrm{pg}$ $\mathrm{TRH} / \mathrm{mg}$ protein, $P<0 \cdot 01, n=6)$.

The initial biochemical characterization of TRH-like peptides was obtained by methanol extraction and by mini-column cation-exchange chromatography using SPSephadex and RIA as described above. As shown in Fig. $2 \mathrm{~A}$, more than $60 \%$ of the total TRH-like immunoreactivity passed through the mini-column without retention. Thus, in addition to retained authentic basic TRH, a great part of the TRH-like peptides represents the neutral or acidic compound. In fact, the later eluting peak was assumed to be authentic TRH because it coeluted with $\left[{ }^{125} \mathrm{I}\right] \mathrm{TRH}$ in this chromatographic system and with synthetic TRH peptide in HPLC (data not shown).

To further discriminate between the acidic or neutral TRH-like peptides not retained in the cation exchange chromatography, the samples of conditioned medium and cell extracts were subjected to anion-exchange chromatography using DEAE-Sephadex and RIA. In Fig. 2B we show one representative chromatographic profile composed of two peaks. An earlier eluting peak (not retained) was assumed to be authentic TRH because it coeluted with $\left[{ }^{125} \mathrm{I}\right] \mathrm{TRH}$ in this system and with the synthetic TRH peptide in HPLC (data not shown) and a retained peak which exhibited HPLC chromatographic properties identical to those of synthetic acidic peptide pGlu-Glu$\mathrm{ProNH}_{2}$ in HPLC (data not shown).

Therefore, endogenous TRH constitutes aproximately $40 \%$ of the total TRH-like immunoreactivity recovered from the HPLC in cells derived from the U-373-MG cell line. It seems that pGlu-Glu-Pro- $\mathrm{NH}_{2}$ is the predominant, if not the only, single TRH-like substance, excluding TRH itself, that we found in this cell line, representing more than $50 \%$ of the total TRH-like immunoreactivity.

In any case, this cell line synthesizes TRH since, in addition to the tripeptide, we were able to detect TRH precursor mRNA using a specific RT-PCR. A representative Southern blot RT-PCR of the product using primers specific for the TRH precursor (pre-TRH) (Fig. 3) showed a band that corresponded to the expected $396 \mathrm{bp}$ fragment in both lanes, hypothalamus (used as a positive control) and U-373-MG cells. No band was observed when the RT step was omitted.

To further investigate whether the expression of these peptide systems is regulated by glucocorticoids, we added dexamethasone $(1 \mu \mathrm{mol} / \mathrm{l})$ to the cell culture for 0.5 up to $24 \mathrm{~h}$ and determined TRH-like substances in culture media and cells. Dexamethasone induced a twofold increase in the TRH content of cells at $2 \mathrm{~h}$ (control $309 \pm 62$ vs $638 \pm 75 \mathrm{pg} \mathrm{TRH} / \mathrm{mg}$ protein at $2 \mathrm{~h}, n=5$ per group, $\quad P<0 \cdot 01)$. On the other hand, in dexamathasone-treated cells, TRH-like substances peaked from $429 \pm 58$ at basal condition to $860 \pm 90 \mathrm{pg}$ $\mathrm{TRH} / \mathrm{mg}$ protein at $6 \mathrm{~h}(n=5$ per group, $P<0 \cdot 01)$. In contrast, no changes were observed in the media for these peptides (data not shown). The M1/M2 muscarinic cholinergic agonist, pilocarpine $(10 \mu \mathrm{mol} / 1,8 \mathrm{~h})$ significantly enhanced the production of both TRH and TRHlike substances (control: $350 \pm 55$ vs pilocarpine: $859 \pm 91$ and control: $484 \pm 65 \mathrm{vs}$ pilocarpine: $1057 \pm 130 \mathrm{pg}$ $\mathrm{TRH} / \mathrm{mg}$ protein respectively $(P<0 \cdot 01, n=4$ per group). In the same experiments, the nicotinic cholinergic agonist, nicotine $(10 \mu \mathrm{mol} / 1,8 \mathrm{~h})$ did not alter TRH (nicotine: $392 \pm 46 \mathrm{pg}$ TRH/mg protein, not significant) whereas it decreased the production of TRH-like substances (nicotine: $114 \pm 38 \mathrm{pg} \mathrm{TRH} / \mathrm{mg}$ protein, $P<0 \cdot 01, n=5$ per group).

\section{Discussion}

Normal brain function requires the presence of diverse interactions between different neurotransmitters and neuropeptides. We have reported the existence of a novel interaction between the cholinergic and TRH systems (García et al. 1992). It is well known that astrocytes express neuropeptides and neurotransmitters, and possess receptors for many neurotransmitters (Murphy \& Pearce 1987, Vernadakis 1988), growth factors and hormones (Chader 1971, Toran-Allerand et al. 1991). The cellular response to these ligands may control the astroglial functional and developmental programme responsible for the astroglial contribution to brain homeostasis. As slices of central nervous system (CNS) are a still unknown complex array of multiple neuronal-glial highly interacting systems, we looked to a human astrocytoma-glioblastoma cell line, U-373-MG, as a simpler model to study neurotransmitter-neuropeptide interactions. The U-373-MG cell line is a progeny of mature astrocytes and probably preserves most of the metabolic features of those nervous cells which are more evident in serum-free cultures where cells became more differentiated and show an astrocyte-like phenotype caracterized by the expression of the GFAP, the major component of the astroglial intermediate filaments.

On the other hand, the identification of the TRH structure, pGlu-His-ProNH ${ }_{2}$, has made possible the production of the synthetic peptide and the generation of 
A

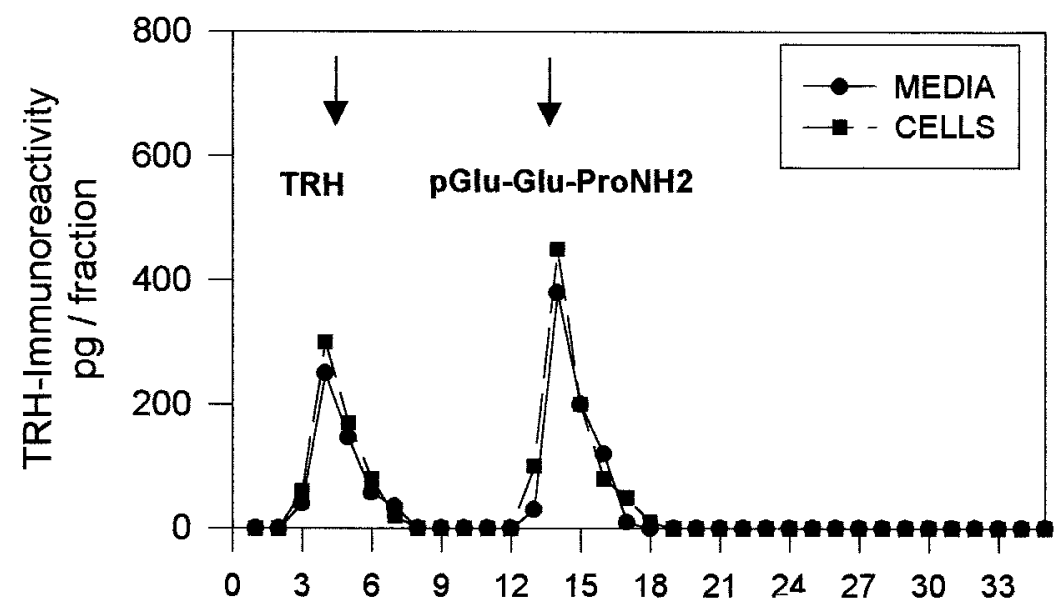

B

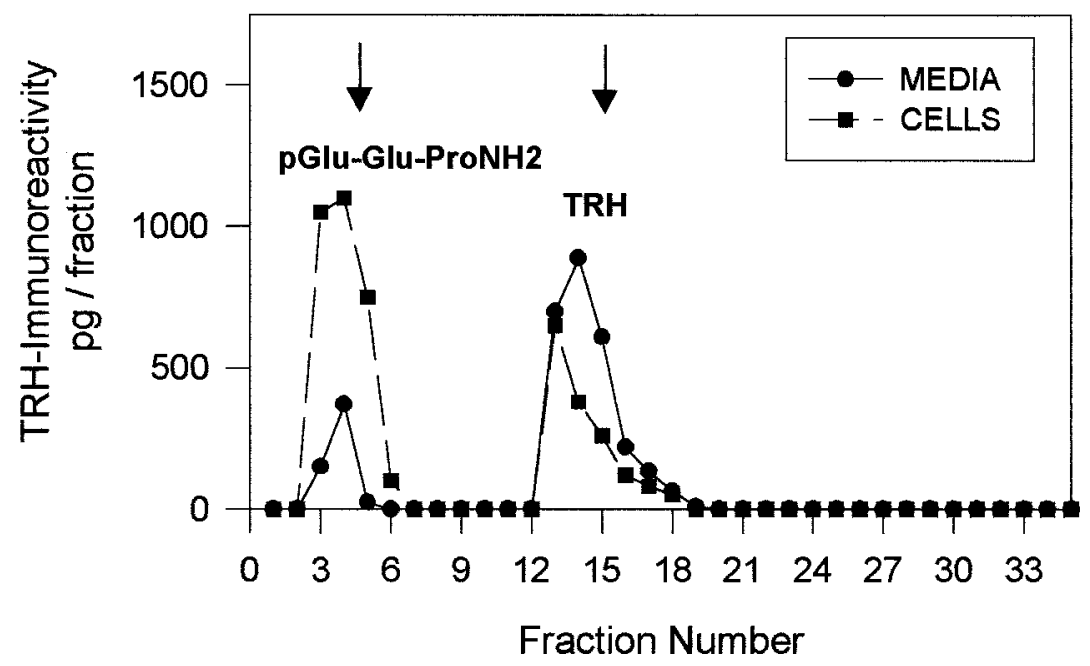

Figure 2 (A) TRH-like peptides extracted from UG-373-MG cells and cell-conditioned medium were resolved by cation exchange chromatography (SP-Sephadex C-25 Superfine, $0.5 \times 6 \mathrm{~cm}$, fraction size $0.5 \mathrm{ml}$ ) in $50 \%$ acetic acid. lodinated TRH and pGlu-Glu-ProNH were used as molecular markers. The elution position of TRH and pGlu-Glu-ProNH $\mathrm{NH}_{2}$ standards are indicated. Aliquots of each fraction were assayed for quantification of TRH-like immunoreactivity. (B) Identical samples were submitted to anion exchange chromatography using DEAE-Sephadex, $0.5 \times 6 \mathrm{~cm}$, fraction size $0.5 \mathrm{ml}$ ) in ammonium acetate buffer $(500 \mathrm{mmol} / \mathrm{l}, \mathrm{pH}$ 7). The same molecular markers as those described above were used. Aliquots of each fraction were assayed for quantification of TRH immunoreactivity.

antisera enabling the screening of tissues for TRH immunoreactivity. It has been reported that $\mathrm{TRH}$ is widely distributed throughout the nervous system and peripheral tissues (Leppaluoto \& Koivusalo 1978, Johansson et al. 1980). These early studies incorrectly assumed that authentic TRH accounted for all of the TRH immunoreactivity detected. In fact, our polyclonal antibody raised by coupling TRH, via histidine, to a large carrier protein recognizes, in a highly specific way, the
N-terminal pyroglutamic acid residue and the C-terminal prolinamide, tolerating central substitutions. Therefore, we used ionic exchange chromatography and HPLC in addition to our RIA to characterize the putative TRH immunoreactivity present in this cell line. Our results indicate that this cell line produces authentic TRH more abundantly in serum-free conditions than in 10\% FCScontaining media. This increase of TRH levels in serumfree cultures suggests that TRH production is dependent 


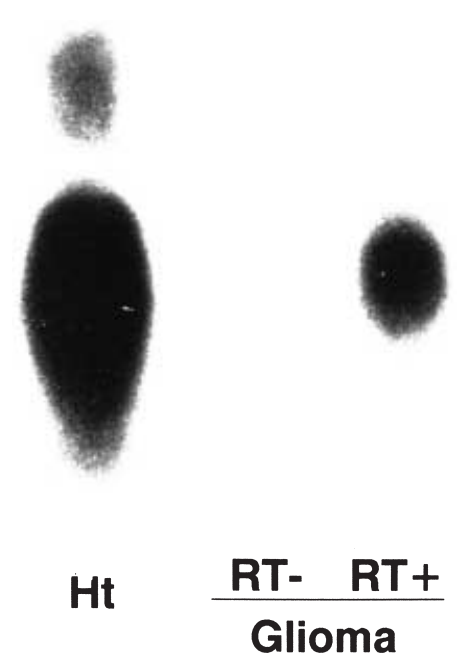

Figure 3 Southern blot of the RT-PCR products from UG-373-MG glioblastoma-astrocytoma cells performed using a $5^{\prime}$ primer and a 3' primer specific for the TRH precursor mRNA. Rat hypothalamus RNA was used as positive control and the negative RT-PCR control was performed by omitting the RT step.

on the differentiation state of cells being a phenotypic trait of mature astrocytes. On the other hand, more experiments are necessary to determine whether a component of the FCS may have a direct inhibitory effect on TRH production. Additionally, RT-PCR analysis specific for the TRH precursor revealed that the tripeptide precursor is synthesized in these cells. The presence of TRH itself indicates that the TRH precursor is processed to the tripeptide, suggesting that this cell line has the appropiate biochemical machinery to do it, as classical TRHproducing cells. Furthermore, the presence of TRH in the cell-conditioned media indicates that these cells are able to release TRH.

At the same time, the combined results of TRH RIA coupled to ion-exchange chromatography and HPLC analysis provide strong evidence for the existence of additional peptides structurally related to TRH in the human astrocytoma-glioblastoma cell line (U-373-MG). Thus, in addition to authentic TRH, only one acidic TRH-related peptide was detected. DEAE-Sephadex chromatography and subsequent HPLC analysis of the fraction corresponding to the retained $\mathrm{TRH}$ immunoreactivity has identified the substance as pGlu-GluProNH $H_{2}$ since it showed identical HPLC chromatographic properties to the synthetic peptide standard. No neutral TRH-related peptides seem to be present, although we cannot exclude the existence of other peptides with similar chromatographic and immunological properties as TRH or pGlu-Glu-ProNH ${ }_{2}$. However, it is clear that the principal TRH-like peptide in these cells is pGluGlu-ProNH $H_{2}$, representing more than $50 \%$ of the total TRH-like immunoreactivity. Similar findings have been reported in different tissues from a variety of species (Khan et al. 1992). A point of caution should be mentioned here; the estimation of the amount of pGlu-Glu-ProNH $\mathrm{H}_{2}$ did not take into account the fact that our antibody raised against TRH shows a $0 \cdot 02-0 \cdot 03 \%$ cross-reaction with the synthetic pGlu-Glu-ProNH $H_{2}$. This may imply that TRHlike substances, measured as equivalent to TRH used as standard in our RIA, may be 600-fold higher than the amount estimated above. If this assumption proves to be true, U-373-MG cells could produce 600-700 more times pGlu-Glu-ProNH $\mathrm{H}_{2}$ than the estimated amount.

It is tempting to speculate that the released $\mathrm{TRH}$ and TRH-like substances may interact in an intracrine, autocrine or paracrine fashion within their own cell or with other neighbour cells of different types where the presence of specific peptide receptors for TRH, but not for TRHlike substances, have been defined. Nevertheless, it will be necessary to investigate whether pGlu-Glu-ProNH $\mathrm{H}_{2}$ and related peptides may serve as autacoid substances in regulating cell functions in the CNS.

In any case, these experiments show for the first time the expression of TRH and pGlu-Glu-ProNH ${ }_{2}$ along with undetectable amounts of neutral or other basic TRHrelated peptides in the human astrocytoma-glioblastoma U-373-MG cell line, indicating that this cell line offers a valuable endocrine model in which biosynthesis, the secretion mechanism, and the interaction of TRH as well as the acidic TRH-related peptide (pGlu-Glu-ProNH ${ }_{2}$ ) with neurotransmitter systems can be investigated. In fact, we found that a variety of stimuli such as serum deprivation and glucocorticoid treatment with dexamethasone were able to increase the TRH and TRHlike substances production in these cells, indicating that the TRH system behaves similarly in other cell lines (Tavianini et al. 1989). In addition, both TRH and pGlu-Glu-ProNH $\mathrm{H}_{2}$ and related peptide production seems to be stimulated by adding to the cell culture a non-selective M1/M2 muscarinic cholinergic agonist, pilocarpine, thus implying that U-373-MG cells have functional muscarinic receptors and that their stimulation activated these peptide systems. This may suggest that glial cells participate in the in vivo TRH-stimulating effect of pilocarpine injected into the rat CNS that we have observed previously (García et al. 1992). This muscarinic action seems to be specific since a nicotinic agonist did not change TRH but inhibited pGlu-Glu-ProNH $\mathrm{H}_{2}$ and related peptide production, while other neuropeptides such as angiotensin II failed to change peptide levels of cultured cells (data not shown).

Finally, as the U-373-MG is a human cell line, our results point out that glial cells in the human CNS may produce authentic TRH and TRH-like substances and suggest that they may also serve as putative neuromodulators in humans. Moreover, these findings may have potential implications in the physiology and pathophysiology of the CNS. 


\section{Acknowledgements}

This work was supported by grants from the University of Buenos Aires (UBA) (ME085) and the Consejo de Nacional de Investigaciones Científicas y Técnicas (CONICET)/Agencia Nacional de Promoción Científica y Tecnológica (PMT-PICT 0427). A L A and S F belong to UBA and S I G, P I P, V N M, S F and C J P belong to CONICET.

\section{References}

Bassiri RM \& Utiger RD 1972 The preparation and specificity of antibody to thyrotropin. Endocrinology 90 722-727.

Boler J, Enzmann F, Folkers K, Bowers CY \& Schally AV 1969 The identity of chemical and hormonal properties of the thyrotropin releasing hormone and pyroglutamyl-histidyl proline amide. Biochemical and Biophysical Research Communication 37 705-710.

Brownstein MJ, Palkovitz M, Saavedra JM, Bassiri RM \& Utiger RD 1974 Thyrotropin-releasing hormone in specific nuclei of rat brain. Science 185 267-269.

Chader GJ 1971 Hormonal effects on the neural retina: induction of glutamine synthetase by cyclic- $3^{\prime}, 5^{\prime}$-AMP. Biochemical and Biophysical Research Communication 43 1102-1105.

Chomczynski P \& Sacchi N 1987 Single-step method RNA isolation by acid guanidinium thiocyanate- phenol-chloroform extraction. Analytical Biochemistry 162 156-159.

Cockle SM, Aitken A, Beg F \& Smyth DG 1989 A novel peptide, pyroglutamylglutamyl proline amide, in the rabbit prostate complex, is structurally related to thyrotropin-releasing hormone. Journal of Biological Chemistry 264 7788-7791.

García SI, Dabsys SM, Santajuliana DO, Delorenzi A, Finkielman S, Nahmod VE \& Pirola CJ 1992 Interaction between thyrotrophin releasing hormone and the muscarinic cholinergic system in rat brain. Journal of Endocrinology 134 215-219.

Gkonos PJ, Kwok CK, Block NL \& Roos BA 1993 Expression of prostatic TRH-like peptides differs between species and between malignant and non malignant tissues. Prostate $\mathbf{2 3}$ 135-147.

Johansson O, Hockfelt T, Jeffcoate SL, White N \& Sternberger LA 1980 Ultra-structural localization of TRH-like immunoreactivity. Experimental Brain Research 38 1-10.

Khan Z, Aitken A, del Rio García J \& Smyth DG 1992 Isolation and identification of two neutral thyrotropin-releasing hormone like peptides, pyroglutamyl-phenylalanine-proline amide and pyroglutamyl-glutamine-proline amide from human seminal fluid. Journal of Biological Chemistry 267 7464-7469.

Lascano EF \& Berria MI 1983 Immunoperoxidase study of astrocytic reaction in Junin virus encephalomyelitis of mice. Acta Neuropathologica 59 183-190.

Leppaluoto J \& Koivusalo R 1978 Thyrotropin releasing factor: distribution in neural and gastrointestinal tissues. Acta Physiologica Scandinavia 104 175-179.

Murphy S \& Pearce B 1987 Functional receptors for neurotransmitters on astrogial cells. Neuroscience 22 381-394.

Pirola CJ, Balda MS, Finkielman S \& Nahmod VE 1983 TRH increases the number of muscarinic receptors in the lateral septal area of the rat brain. Brain Research 273 387-391.

del Rio-García J \& Smyth DG 1990 Distribution of pyroglutamilpeptide amides related to thyrotrophin-releasing hormone in the central nervous system and periphery of the rat. Journal of Endocrinology 127 445-450.

Tavianini MA, Gkonos PJ, Lampe TH \& Roos BA 1989 Dexamethasone stimulates thyrotropin releasing hormone production in a C cell line. Molecular Endocrinology 3 605-610.

Toran-Allerand DC, Bentham W, Miranda RC \& Anderson JP 1991 Insulin influences astroglial morphology organotypic cultures. Brain Research 558 296-304.

Vernadakis A 1988 Neuron-glia interrelations. International Reviews in Neurobiology 30 149-224.

Received 20 September 1999

Revised manuscript received 11 April 2000

Accepted 18 August 2000 